\title{
各種測定法による硬さの換算法に関する研究委員会報告*
}

\author{
各種測定法による硬さの換算法に関する研究委員会
}

\section{Report of Research Committee for Hardness Conversion in Various Hardness Tests}

\author{
Research Committee on Hardness Conversion in Various Hardness Tests
}

\begin{abstract}
In spring factory, large size springs are manufactured in hot forming process. In many cases, the hardness of hot formed springs is inspected by Brinell hardness test. The quality agreement between customer and manufacturer on hardness is often established by other hardness like Vickers and Rockwell hardness, though the spring hardness quality control in shop floor is done by Brinell hardness. Therefore, hardness conversion is often carried out. SAE-J417 has been used for the hardness conversion in the spring industry for this purpose. However, it is often said that the hardness conversion value is not adequate in the area where the hardness is higher than conventional area. This committee started on investigating the difference between SAE-J417 conversion data and various spring hardness test data on June 2007. The purpose of this committee is to offer the new conversion data between various hardness tests for the spring steel and to establish JSMA standard. As a result of three years activity, following findings were obtained.

(1) It has been understood that the correlation in Brinell hardness, Rockwell hardness and Vickers hardness is not necessarily correct in SAE-J417 data as the result of various hardness tests on SUP9 spring steel.

(2) The dispersion was $\pm 1.5 \%$ in maximum when measuring the hardness by Brinell hardness tester, Rockwell hardness tester and Vickers hardness tester.

(3) The dispersion was about one percent as a result of investigating the influence of testing load in Vickers hardness measuring.

(4) The correlation between various hardness tests using several grades of spring steel did not show clear difference by steel grades. (So, the committee made a new conversion table for spring steel by treating all the data from different steel grades as data from one grade.)
\end{abstract}

Key Words : SAE-J417, Hardness, Spring Steels, SUP9, Conversion

\section{1. 目的}

ばね業界の製造現場では，大きさが比較的大きいばねは 熱間成形される場合が多く，その管理は (Fig. 1参照), 工 程内で検査が可能かつ検査後のワークを廃却しないで済む ブリネル硬さ試験を適用している。品質管理はブリネル硬 さ試験で実施しているが，品質協定はビッカース硬さやロ
ックウェル硬さなど他の硬さで規定されていることがある. また逆に，ブリネル硬さで規定されている製品であっても， 客先や開発現場ではブリネル試験が容易でない場合もあり, ロックウェル硬さやビッカース硬さ試験での評価が行われ ることもある，また，同一の製品であっても，使用される 国によってロックウェル硬さで規定されているものやブリ

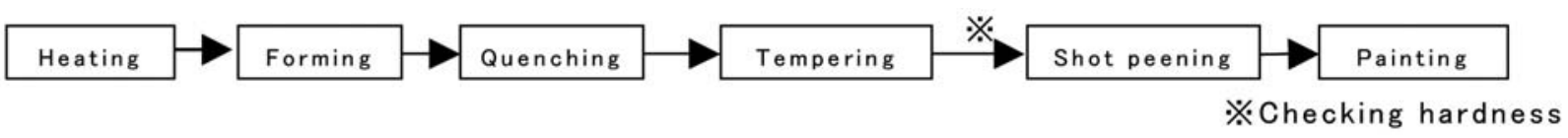

Fig. 1 Main manufacturing process of hot formed springs. 
ネル硬さで規定されているものがある。そのため，製造現 場の硬さ試験と開発現場, 客先, 国別での硬さ試験は異な る場合が多々あり，各種硬さ試験間の換算は日常的に行わ れている。試験間の硬さ換算をばね業界では硬さ換算表 SAE-J417を従来から用いてきた。ばねの実用硬さ域は概ね 200-700HVであるが，ばねの硬さが硬い領域において各種 硬さ測定法の換算値は不整合であるとの情報が寄せられて いる。硬さ換算しなければならない事例や換算値の不整合 例をFig. 2に示す。硬さ換算に関する研究はいくつかなされ ている ${ }^{1)}$ が，研究されている硬さ域がばねに比べて低く， ばねに扔ける硬さ換算の知見は少ないといえる。

このような背景のもと本委員会では, SAE-J417換算表と ばね鋼の各種硬さ試験間の相関デー夕との違いについて 2007年6月より調査を開始した。目的はばね鋼を対象として， 各種測定法間の新たな換算表を提供すること，およびJSMA 規格化することである.

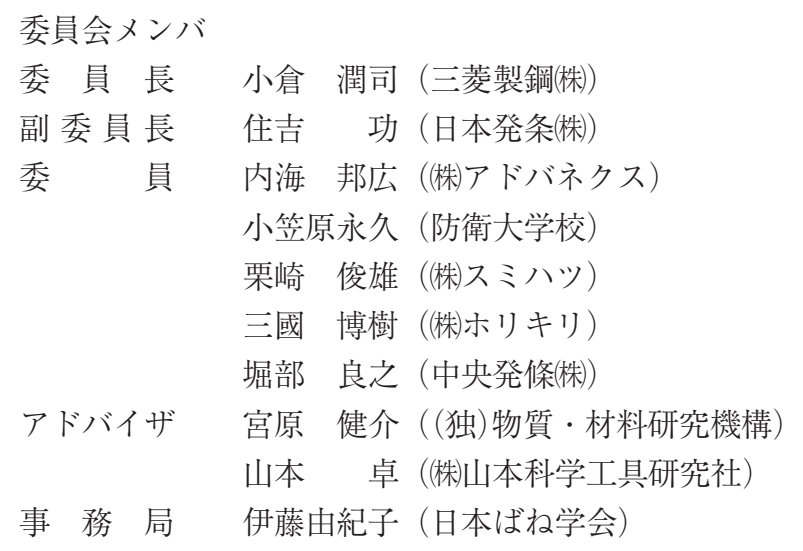

\section{2. 実験の方向性}

実験の方向性を決めるために各社で実施している硬さ試 験方法を調査したところ，ブリネル硬さ，ロックウェル硬 さ，ビッカース硬さ試験を実施するのは熱間ばねが主であ った。小物ばねにはマイクロビッカース硬さ試験が多く用 いられて抢り，引張強さとの相関も重要視するとのことで あった。また，硬さを決定する様々な要因についてディス カッションした結果，以下のような意見が出された。

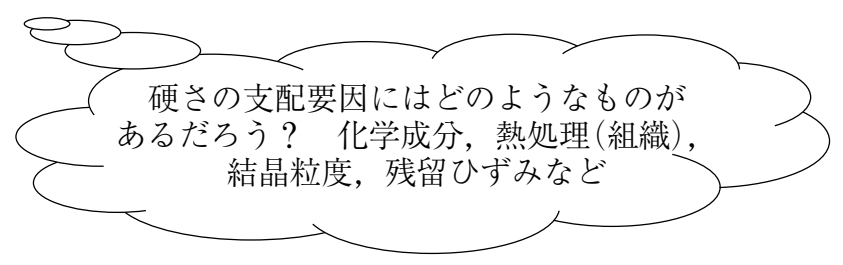

（1）いくつもの硬さ試験を1断面内で実施したく, 径の太い 材料で試験すべきである。

（2）径が太くてもできるだけ均一な熱処理組織が得られる 材料で試験すべきである。

(3) ベースデータの作成が目的であるので材料（化学成分） は絞ったほうがよい。また，多くの分野で利用されてい るばね鋼が望ましい。
（4）幅広い硬さ領域について調査する必要があり，広範に 調質できる材料が望ましい.

（5）材料（化学成分）による差が明瞭か確認すべきである.

（6）測定したデー夕には試験機の機差も含まれるため，機 差について検討すべきである.

（7）硬さ試験時の条件はできるだけ同じにすべきである.

上記をもとに実験に用いるべースの材料にはSUP9 $\phi 31 \mathrm{~mm}$ を選定した。鋼種の違いについて検討すべく各社 で量産されているばねの硬さ（材質：S45C，S48C, SUP11A，SUP12V，SCM435，SCM822）を追加で調査した。 各社の試験機差について検討すべく, 山本科学工具研究社 製ビッカース基準片でラウンドロビン試験することとした。 硬さ試験条件の影響として埋込み樹脂の硬さ值への影響, ビッカース硬さ試験における試験荷重の影響について検討 することとした。本委員会での試験の流れ・概略（フロー チャート）をFig. 3に示す。なお，冷間ばねでの調査は残留 ひずみによる硬度ばらつきが生ずるため，デー夕の取扱い が難しくなることが予測されるので除外した。

\section{3. 硬さ変化要因の検討}

\section{1 機差の影響}

テストピースは山本科学工具研究社製のビッカース硬さ 基準片 $300 \mathrm{HV} ， 500 \mathrm{HV} ， 700 \mathrm{HV}$ であ。試験条件及び方法は ・ブリネル硬さ試験（HBW）：10mm球圧子，荷重 $3000 \mathrm{kgf}$

・ロックウェル硬さ試験（HRC）：ダイヤモンド圧子，荷重 $150 \mathrm{kgf}$

・ビッカース硬さ試験（HV）：ダイヤモンド圧子，荷重 $0.1-30 \mathrm{kgf}$

圧痕間隔はJIS規格を参考に圧痕径の3倍以上とる（Fig. 4 参考)．同一のテストピースを用いてラウンドロビン試験を 実施した。

評価指標は式（1）の值をばらつき值とした．各種硬さ試 験の結果，試験機が異なることによるデー夕ばらつきは最 大で $1.5 \%$ 程度であった。

ばらつき值 $=\left(\mathrm{H}_{\text {ave }}-\mathrm{H}_{\text {tave }}\right) / \mathrm{H}_{\text {tave }}$

$\mathrm{H}_{\text {ave }}$ : 各社平均值

$\mathrm{H}_{\mathrm{tave}}$ : 全デー夕平均值

ブリネル硬さ試験（Table 1，2，3，Fig. 5，6）

ロックウェル硬さ試験（Table 4，5，6， Fig. 7，8）

ビッカース硬さ試験（Table 7，8，9，Fig. 9，10）

\section{2 ビッカース硬さに対する試験荷重の影響}

3.1のビッカース硬さ試験は試験荷重の影響についても検 討したこととなる. Fig. 9, Table 7，8，9の結果を参照すれ ば，0.1kgf，1kgf，10kgf，30kgfの荷重の影響は $1 \%$ 程度であ り，ブリネル硬さ試験のばらつきより小さいレベルといえ る。よって, 本試験では試験荷重の影響はないと判断して 異なる試験荷重のビッカース硬さを一つのデータとして取 り扱うこととした。 


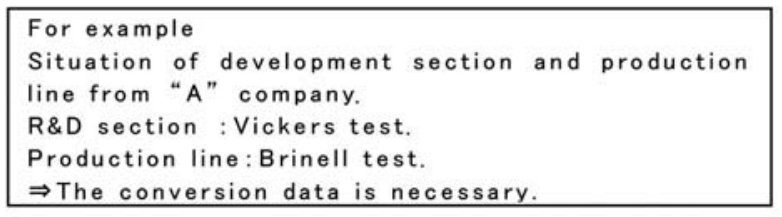

Situation of production line from "C" overseas. Range of hardness in drawing : Rockwell data. Production line: Managed by Brinell test.

$\Rightarrow$ The conversion data is necessary.

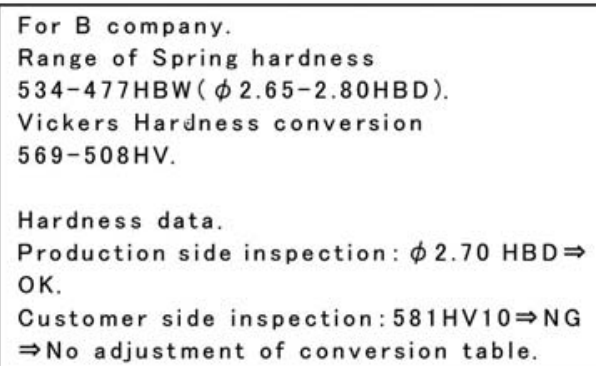

Fig. 2 The case of adjustment or non- adjustment in hardness conversion.

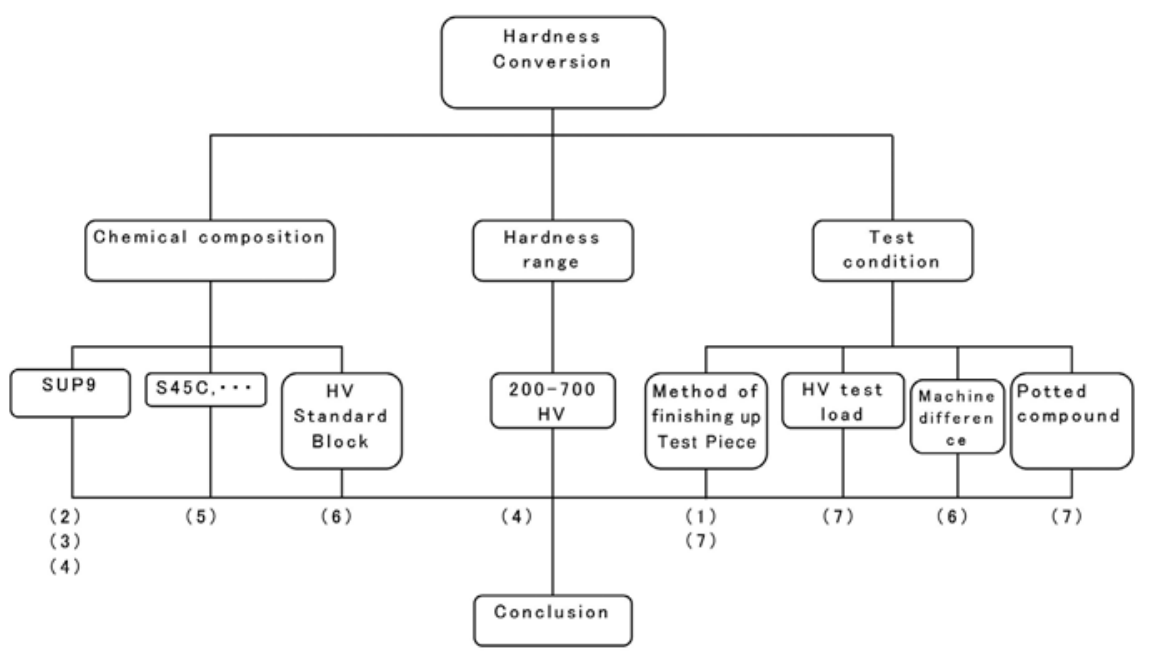

Fig. 3 Study items and flow chart.
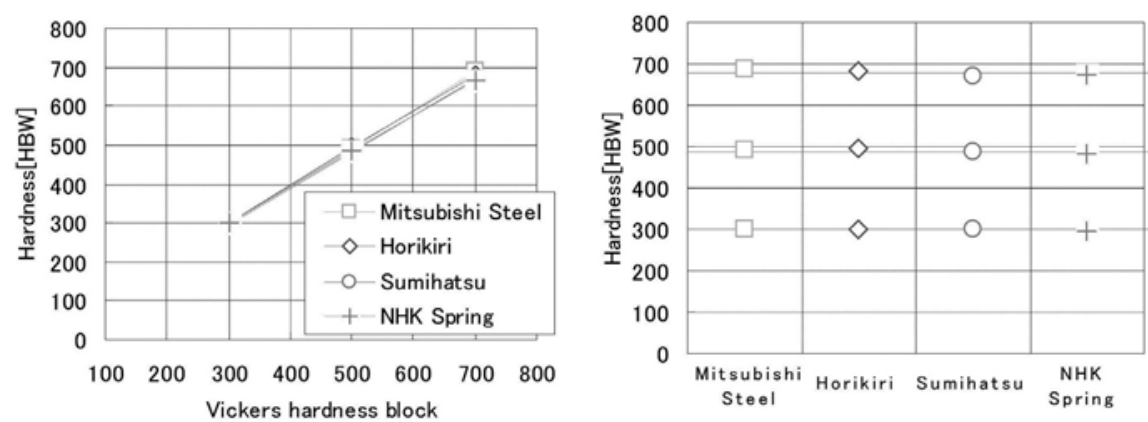

Fig. 5 Brinell hardness (mean value).
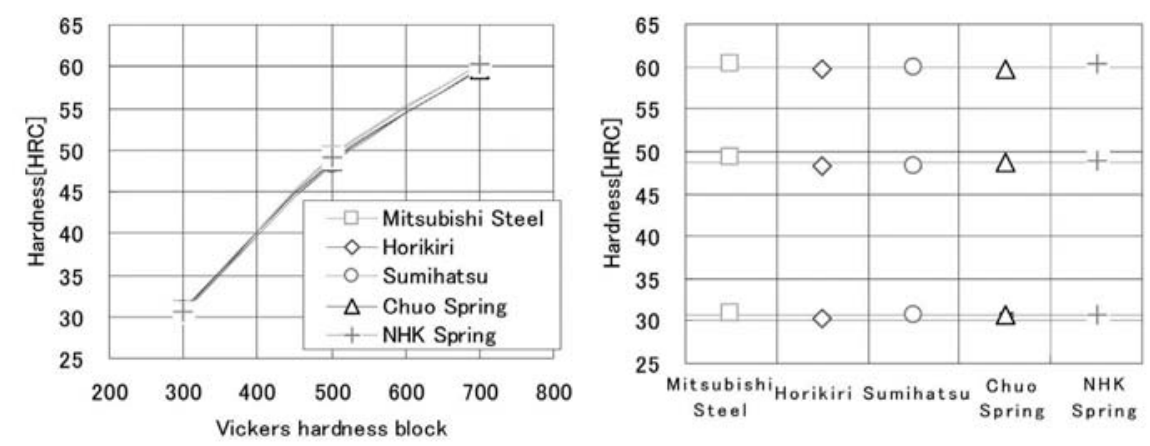

Fig. 7 Rockwell hardness (mean value).

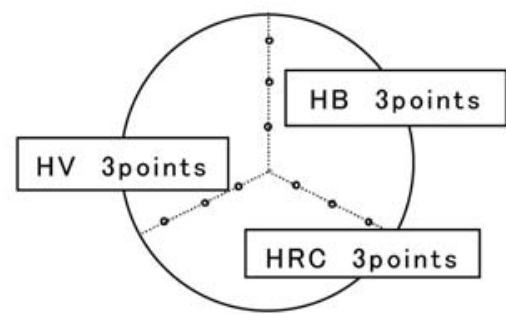

Fig. 4 Method of hardness tests.

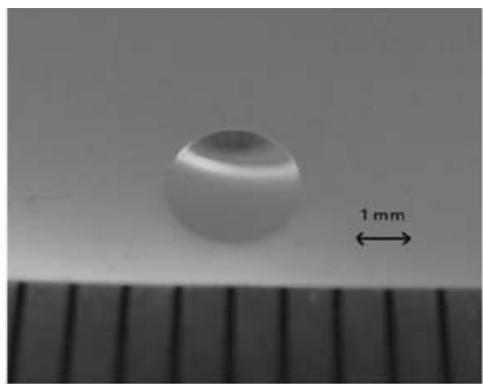

Fig. 6 A Brinell hardness impression.

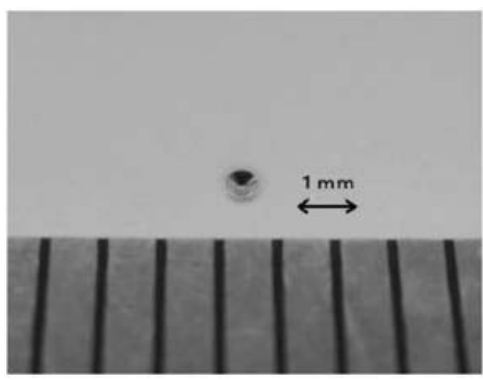

Fig. 8 A Rockwell hardness impression. 

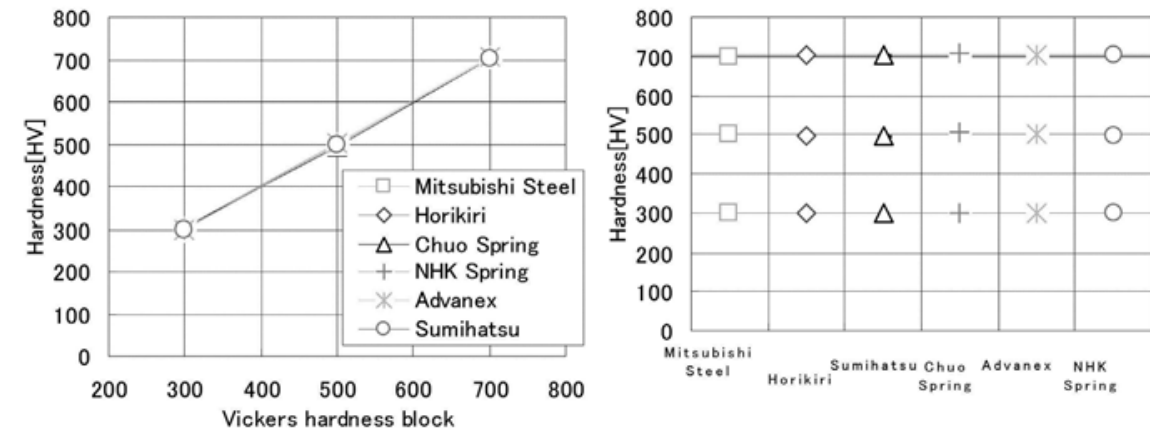

Fig. 9 Vickers hardness (mean value).

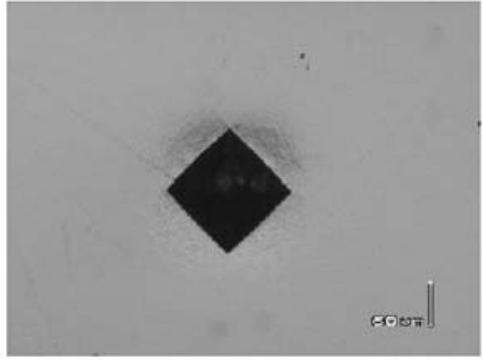

Fig. 10 A Vickers hardness impression.
Table 1 Brinell hardness in 700HV standardized blocks.

\begin{tabular}{|c|c|c|c|c|}
\hline $\begin{array}{c}\text { Average of all data: } \\
677.5 \mathrm{HBW}\end{array}$ & $\begin{array}{c}\text { Mitsubishi } \\
\text { Steel }\end{array}$ & Horikiri & Sumihatsu & NHK Spring \\
\hline Average & $688.0 \mathrm{HBW}$ & $682.0 \mathrm{HBW}$ & $672.0 \mathrm{HBW}$ & $667.9 \mathrm{HBW}$ \\
\hline Maximum data & $688.0 \mathrm{HBW}$ & $682.0 \mathrm{HBW}$ & $676.0 \mathrm{HBW}$ & $671.7 \mathrm{HBW}$ \\
\hline Minimum data & $688.0 \mathrm{HBW}$ & $682.0 \mathrm{HBW}$ & $670.0 \mathrm{HBW}$ & $661.0 \mathrm{HBW}$ \\
\hline Difference to average & $+1.55 \%$ & $+0.67 \%$ & $-0.81 \%$ & $-1.41 \%$ \\
\hline
\end{tabular}

Table 3 Brinell hardness in 300HV standardized blocks.

\begin{tabular}{|c|c|c|c|c|}
\hline $\begin{array}{c}\text { Average of all data: } \\
299.1 \mathrm{HBW}\end{array}$ & $\begin{array}{c}\text { Mitsubishi } \\
\text { Steel }\end{array}$ & Horikiri & Sumihatsu & NHK Spring \\
\hline Average & $299.3 \mathrm{HBW}$ & $302.0 \mathrm{HBW}$ & $296.0 \mathrm{HBW}$ & $298.9 \mathrm{HBW}$ \\
\hline Maximum data & $302.0 \mathrm{HBW}$ & $302.0 \mathrm{HBW}$ & $298.0 \mathrm{HBW}$ & $299.2 \mathrm{HBW}$ \\
\hline Minimum data & $298.0 \mathrm{HBW}$ & $302.0 \mathrm{HBW}$ & $295.0 \mathrm{HBW}$ & $298.7 \mathrm{HBW}$ \\
\hline Difference to average & $\pm 0 \%$ & $+0.98 \%$ & $-1.02 \%$ & $\pm 0 \%$ \\
\hline
\end{tabular}

Table 5 Rockwell hardness in 500HV standardized blocks.

\begin{tabular}{|c|c|c|c|c|c|}
\hline $\begin{array}{c}\text { Averase of all data: } \\
\text { 48.7HRC }\end{array}$ & $\begin{array}{c}\text { Mitsubishi } \\
\text { Steel }\end{array}$ & Horikiri & Sumihatsu & Chuo Spring & NHK Spring \\
\hline Average & $49.2 \mathrm{HRC}$ & $48.4 \mathrm{HRC}$ & $48.2 \mathrm{HRC}$ & $48.6 \mathrm{HRC}$ & $49.0 \mathrm{HRC}$ \\
\hline Maximum data & $49.3 \mathrm{HRC}$ & $48.8 \mathrm{HRC}$ & $48.4 \mathrm{HRC}$ & $48.8 \mathrm{HRC}$ & $49.1 \mathrm{HRC}$ \\
\hline Minimum data & $49.2 \mathrm{HRC}$ & $48.0 \mathrm{HRC}$ & $48.0 \mathrm{HRC}$ & $48.3 \mathrm{HRC}$ & $48.9 \mathrm{HRC}$ \\
\hline Difference to average & $+1.14 \mathrm{~s}$ & $-0.64 \mathrm{5}$ & -0.995 & -0.165 & +0.665 \\
\hline
\end{tabular}

Table 7 Vickers hardness in 700HV standardized blocks.

\begin{tabular}{|c|c|c|c|c|c|c|}
\hline $\begin{array}{c}\text { Average of all data: } \\
\text { 703.5 }\end{array}$ & $\begin{array}{c}\text { Mitsubishi } \\
\text { Steel } \\
30 \mathrm{kgf}\end{array}$ & $\begin{array}{c}\text { Horikiri } \\
30 \mathrm{kgf}\end{array}$ & $\begin{array}{c}\text { Sumihatsu } \\
10 \mathrm{kgf}\end{array}$ & $\begin{array}{c}\text { Chuo } \\
\text { Spring } \\
0.1 \mathrm{kgf}\end{array}$ & $\begin{array}{c}\text { Advanex } \\
0.1 \mathrm{kgf}\end{array}$ & $\begin{array}{c}\text { NHK } \\
\text { Spring } \\
1 \mathrm{kgf}\end{array}$ \\
\hline Average & $701.0 \mathrm{HV}$ & $701.8 \mathrm{HV}$ & $704.0 \mathrm{HV}$ & $701.3 \mathrm{HV}$ & $704.7 \mathrm{HV}$ & $708.1 \mathrm{HV}$ \\
\hline Maximum data & $705.0 \mathrm{HV}$ & $703.7 \mathrm{HV}$ & $707.0 \mathrm{HV}$ & $702.4 \mathrm{HV}$ & $706.0 \mathrm{HV}$ & $712.7 \mathrm{HV}$ \\
\hline Minimum data & $699.0 \mathrm{HV}$ & $699.1 \mathrm{HV}$ & $698.0 \mathrm{HV}$ & $699.9 \mathrm{HV}$ & $704.0 \mathrm{HV}$ & $704.6 \mathrm{HV}$ \\
\hline Difference to average & $-0.35 \mathrm{~S}$ & $-0.24 \mathrm{~s}$ & $+0.08 \mathrm{~s}$ & -0.315 & $+0.17 \mathrm{~s}$ & $+0.65 \mathrm{~s}$ \\
\hline
\end{tabular}

Table 9 Vickers hardness in 300HV standardized blocks.

\begin{tabular}{|c|c|c|c|c|c|c|}
\hline $\begin{array}{c}\text { Average of oll data: } \\
299.7 \mathrm{HV}\end{array}$ & $\begin{array}{c}\text { Mitsubishi } \\
\text { Steel } \\
30 \mathrm{kgf}\end{array}$ & $\begin{array}{c}\text { Horikiri } \\
30 \mathrm{kgf}\end{array}$ & $\begin{array}{c}\text { Sumihatsu } \\
10 \mathrm{kgf}\end{array}$ & $\begin{array}{c}\text { Chuo } \\
\text { Spring } \\
0.1 \mathrm{kgf}\end{array}$ & $\begin{array}{c}\text { Advanex } \\
0.1 \mathrm{kgf}\end{array}$ & $\begin{array}{c}\text { NHK } \\
\text { Spring } \\
1 \mathrm{kgf}\end{array}$ \\
\hline Average & $299.3 \mathrm{HV}$ & $299.7 \mathrm{HV}$ & $300.0 \mathrm{HV}$ & $300.4 \mathrm{HV}$ & $298.0 \mathrm{HV}$ & $301.0 \mathrm{HV}$ \\
\hline Maximum data & $301.0 \mathrm{HV}$ & $300.0 \mathrm{HV}$ & $302.0 \mathrm{HV}$ & $301.1 \mathrm{HV}$ & $299.0 \mathrm{HV}$ & $305.1 \mathrm{HV}$ \\
\hline Minimum data & $298.0 \mathrm{HV}$ & $299.5 \mathrm{HV}$ & $299.0 \mathrm{HV}$ & $299.6 \mathrm{HV}$ & $296.0 \mathrm{HV}$ & $298.8 \mathrm{HV}$ \\
\hline Difference to average & -0.14 & \pm 0 & +0.08 & +0.22 & -0.58 & +0.43 \\
\hline
\end{tabular}

Table 2 Brinell hardness in 500HV standardized blocks.

\begin{tabular}{|c|c|c|c|c|}
\hline $\begin{array}{c}\text { Average of all data: } \\
488.6 \mathrm{HBW}\end{array}$ & $\begin{array}{c}\text { Mitsubishi } \\
\text { Steel }\end{array}$ & Horikiri & Sumihatsu & NHK Spring \\
\hline Average & $492.0 \mathrm{HBW}$ & $495.0 \mathrm{HBW}$ & $482.3 \mathrm{HBW}$ & $484.9 \mathrm{HBW}$ \\
\hline Maximum data & $492.0 \mathrm{HBW}$ & $495.0 \mathrm{HBW}$ & $485.0 \mathrm{HBW}$ & $488.6 \mathrm{HBW}$ \\
\hline Minimum data & $492.0 \mathrm{HBW}$ & $495.0 \mathrm{HBW}$ & $477.0 \mathrm{HBW}$ & $482.5 \mathrm{HBW}$ \\
\hline Difference to average & $+0.71 \%$ & $+1.32 \%$ & $-1.27 \%$ & $-0.75 \%$ \\
\hline
\end{tabular}

Table 4 Rockwell hardness in 700HV standardized blocks.

\begin{tabular}{|c|c|c|c|c|c|}
\hline Averase of all data: 60.0HRC & $\begin{array}{c}\text { Mitsubishi } \\
\text { Steel }\end{array}$ & Horikiri & Sumihatsu & Chuo Spring & NHK Spring \\
\hline Average & $60.4 \mathrm{HRC}$ & $59.8 \mathrm{HRC}$ & $59.9 \mathrm{HRC}$ & $59.7 \mathrm{HRC}$ & $60.3 \mathrm{HRC}$ \\
\hline Maximum data & $60.4 \mathrm{HRC}$ & $59.9 \mathrm{HRC}$ & $60.0 \mathrm{HRC}$ & $59.8 \mathrm{HRC}$ & $60.5 \mathrm{HRC}$ \\
\hline Minimum data & $60.3 \mathrm{HRC}$ & $59.6 \mathrm{HRC}$ & $59.7 \mathrm{HRC}$ & $59.6 \mathrm{HRC}$ & $60.2 \mathrm{HRC}$ \\
\hline Difference to average & $+0.59 \mathrm{~S}$ & $-0.36 \mathrm{~s}$ & $-0.24 \mathrm{~s}$ & $-0.52 \mathrm{~s}$ & $+0.53 \mathrm{~s}$ \\
\hline
\end{tabular}

Table 6 Rockwell hardness in 300HV standardized blocks.

\begin{tabular}{|c|c|c|c|c|c|}
\hline $\begin{array}{c}\text { Average of all data: } \\
\text { 30.7HRC }\end{array}$ & $\begin{array}{c}\text { Mitsubishi } \\
\text { Steel }\end{array}$ & Horikiri & Sumihatsu & Chuo Spring & NHK Spring \\
\hline Average & $30.8 \mathrm{HRC}$ & $30.4 \mathrm{HRC}$ & $30.7 \mathrm{HRC}$ & $30.7 \mathrm{HRC}$ & $30.6 \mathrm{HRC}$ \\
\hline Maximum data & $30.9 \mathrm{HRC}$ & $30.5 \mathrm{HRC}$ & $30.8 \mathrm{HRC}$ & $30.9 \mathrm{HRC}$ & $31.1 \mathrm{HRC}$ \\
\hline Minimum data & $30.7 \mathrm{HRC}$ & $30.2 \mathrm{HRC}$ & $30.7 \mathrm{HRC}$ & $30.5 \mathrm{HRC}$ & $30.3 \mathrm{HRC}$ \\
\hline Difference to average & $+0.57 \mathrm{~s}$ & $-0.96 \mathrm{5}$ & $+0.24 \mathrm{~s}$ & $+0.24 \mathrm{~s}$ & $-0.09 \mathrm{~s}$ \\
\hline
\end{tabular}

Table 8 Vickers hardness in 500HV standardized blocks.

\begin{tabular}{|c|c|c|c|c|c|c|}
\hline $\begin{array}{c}\text { Average of all date: } \\
498.8 \mathrm{HV}\end{array}$ & $\begin{array}{c}\text { Mitsubishi } \\
\text { Steel } \\
30 \mathrm{kgf}\end{array}$ & $\begin{array}{c}\text { Horikiri } \\
30 \mathrm{kgf}\end{array}$ & $\begin{array}{c}\text { Sumihatsu } \\
10 \mathrm{kgf}\end{array}$ & $\begin{array}{c}\text { Chuo } \\
\text { Spring } \\
0.1 \mathrm{kgf}\end{array}$ & $\begin{array}{c}\text { Advanex } \\
0.1 \mathrm{kgf}\end{array}$ & $\begin{array}{c}\text { NHK } \\
\begin{array}{c}\text { Spring } \\
1 \mathrm{kgf}\end{array}\end{array}$ \\
\hline Average & $497.3 \mathrm{HV}$ & $498.3 \mathrm{HV}$ & $496.3 \mathrm{HV}$ & $495.3 \mathrm{HV}$ & $501.7 \mathrm{HV}$ & $504.1 \mathrm{HV}$ \\
\hline Maximum data & $499.0 \mathrm{HV}$ & $500.8 \mathrm{HV}$ & $503.0 \mathrm{HV}$ & $497.6 \mathrm{HV}$ & $503.0 \mathrm{HV}$ & $519.5 \mathrm{HV}$ \\
\hline Minimum data & $495.0 \mathrm{HV}$ & $496.1 \mathrm{HV}$ & $493.0 \mathrm{HV}$ & $493.0 \mathrm{HV}$ & $501.0 \mathrm{HV}$ & $500.4 \mathrm{HV}$ \\
\hline Difference to average & $-0.30 \mathrm{~S}$ & $-0.11 \mathrm{~S}$ & $-0.50 \mathrm{~S}$ & $-0.71 \mathrm{5}$ & $+0.57 \mathrm{~s}$ & $+1.05 \mathrm{~S}$ \\
\hline
\end{tabular}




\section{3 埋込み樹脂の影響}

埋込み樹脂有無による硬さへの影響をロックウェル硬さ 試験 (HRC), ビッカース硬さ試験（30kgf）で比較した。 試験片はSCM435板厚 $20 \mathrm{~mm}$ 材, 450HVに調質したものと, SUP11A板厚16mm材の素材のままのものである。試料は断 面を切断して埋込み樹脂有無で準備し，断面をエメリー紙 で研磨後，バフにて鏡面仕上げとした。試験は $\mathrm{t} / 4$ 部に8点 ずつ実施した。試験の結果をFig. 11に示す。ビッカース硬 さ試験では埋め込み樹脂の差は認められなかったが，ロッ クウェル硬さ試験では差が認められた。よって, ブリネル, ロックウェル，ビッカース硬さ試験を同一サンプルで実施 するためには鋼材のまま研磨して使用すべきである.

\section{1 供試材料}

\section{SUP9を用いた硬さ試験片の調査}

供試材SUP9の化学成分を Table 10に示す。寸法は $\phi 31 \mathrm{~mm} \times 100 \mathrm{~mm}$ の丸棒材であった。

\section{2 熱処理条件}

焼入れ : $900^{\circ} \mathrm{C} \times 20 \mathrm{~min}$ 在炉後, 油焼入れ

焼戻し: $300^{\circ} \mathrm{C}(600 \mathrm{HV}), 410^{\circ} \mathrm{C}(500 \mathrm{HV}), 525^{\circ} \mathrm{C}(400 \mathrm{HV})$, $660^{\circ} \mathrm{C}(300 \mathrm{HV})$ 在炉1時間

\section{3 テストピース作製方法}

厚さ $20 \mathrm{~mm} に$ 切断して, 平面研削後, エメリ一紙研磨, バフによる鏡面仕上げとした。

\section{4 熱処理組織調查}

組織調査の結果をFig. 12に示す。内部組織は焼戻しマル テンサイトであった。

\section{5 硬さ分布調查}

硬さ分布調查方法をFig. 13に，調査した結果をFig. 14に 示す. 結果より, 中心付近のデータへの影響を考慮して硬 さの調査部位は $\mathrm{D} / 4$ 部に統一した。なお，他の量産ばねの 調査についても $\mathrm{D} / 4 も し く は \mathrm{t} / 4$ 部の調査に統一した。

\section{6 各種硬さ試験結果}

1つのテストピースに対してFig. 15に示すように各種硬さ 試験を4点ずつランダムに実施して平均值を求めた。

各種硬さ試験を実施し, HRC-HVの相関をFig. 16, HBWHVの相関をFig. 17，HBW-HRCの相関をFig. 18にそれぞれ 示す.

HRC-HVの相関では500HV〜600HVのデータにおいて， SAE換算よりもビッカース硬さが高めとなっている. HBWHVの相関では全域において, SAE換算よりもビッカース硬 さがやや低めとなっている，HBW-HRCの相関では全域に おいて，SAE換算よりもロックウェルが低めとなっている.

\section{7 考察}

鋼種の違いによる硬さの相関関係はFig. 16，17，18より SUP9，ビッカース基準片，量産ばね鋼それぞれに明瞭な違 いは認めらない．よって全実験データを1つのデータとして 取扱うこととした。1つのデータとしてまとめたものを Fig. 19, 20, 21に示す. 全実験デー夕の近似曲線とSAE-J417 の曲線にはいずれの相関関倸に扔いても一致していないこ とがわかる.

換算表の作成にあたり，SAE-J417の起源について調査し たところ，SAEの硬さ換算表は本委員会の活動と同様に広 範な硬さの測定デー夕をもとに得られた近似曲線, 近似式 から作成されていることがわかった2). よって，本委員会に おいても実験デー夕から得られた近似曲線, 近似式から換 算表を作成して差し支えないものと判断し，新たに換算表 を作成した.HRC-HVの換算表をTable 11，HBW-HVの換算 表をTable 12, HBW-HRCの換算表をTable 13にそれぞれ示 す.

\section{5. まとめ}

ばね鋼を対象として各種測定法間の新たな硬さ換算表を 提供するために委員会活動を実施し，以下の結果が得られ た.

（1）焼戻しにより硬さを 4 水準に変化させたSUP9，硬さ3水 準のビッカース基準片, 各社製品の量産ばねに対して各 種硬さ試験を実施した結果, ブリネル硬さ，ロックウェ ル硬さ，ビッカース硬さの相関関倸はSAE-J417と必ずし も一致しないことがわかった.

（2）各社のブリネル硬さ，ロックウェル硬さ，ビッカース 硬さ試験機の機差を検討した結果，ばらつきはいずれの 試験機においても最大で $1.5 \%$ 程度であった。

（3）ビッカース硬さ試験の試験荷重による硬さへの影響を 調査した結果, ばらつきは $1 \%$ 程度であった。

（4）SUP9, ビッカース基準片, 各社量産ば対鋼の各種硬さ 試験との相関関倸には鋼種による明瞭な違いは認められ ず，1つのデータとして取扱い換算表を作成した。

\section{参考文献}

1）吉沢武男編，硬さ試験法とその応用，裳華房 (昭和 42), 291-297.

2) ASTM E140-07, (2007). 

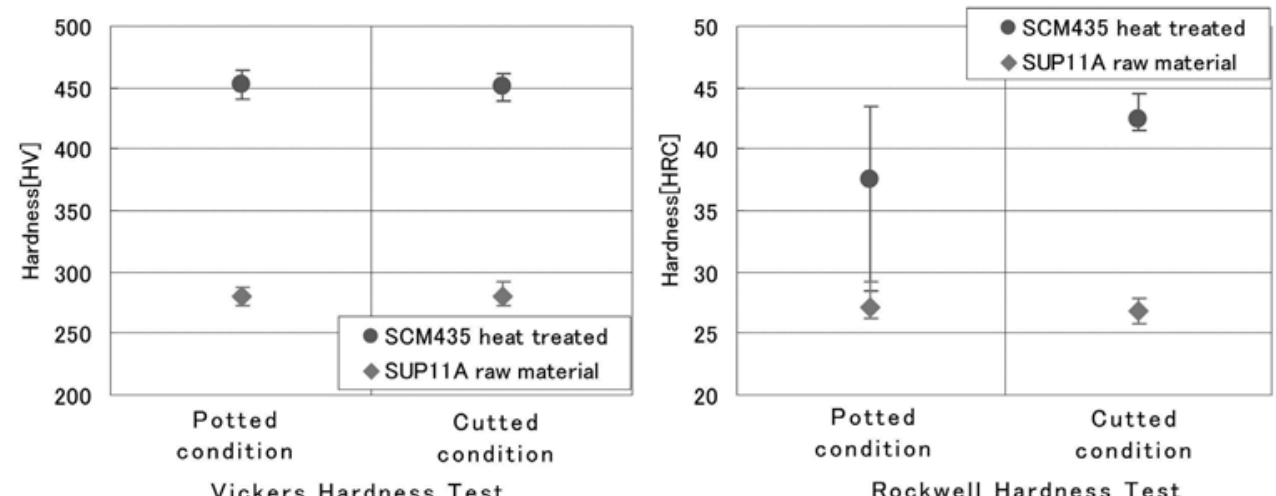

Fig. 11 Influence of mold resin on hardness.

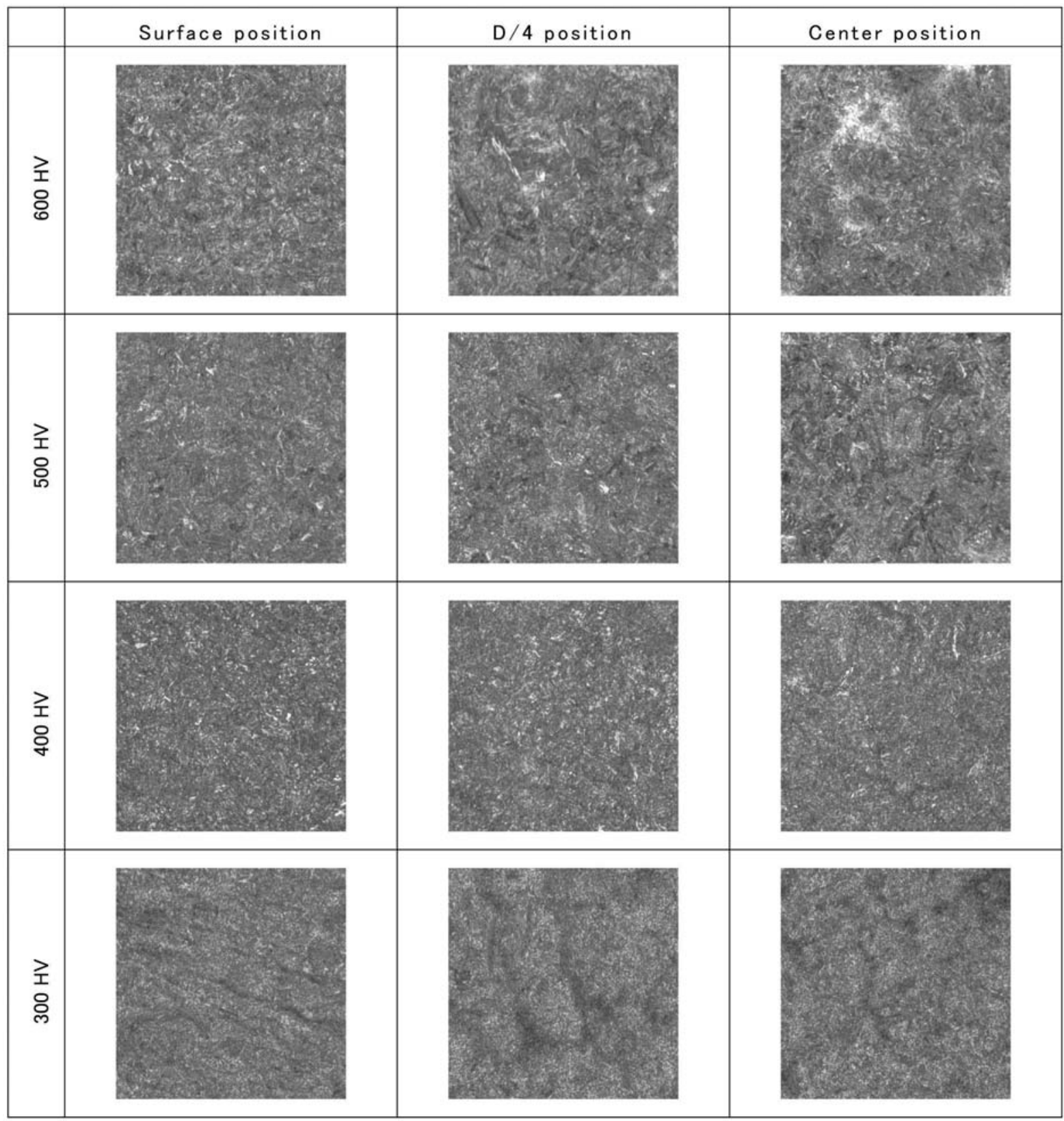

Fig. 12 Microstructure of SUP9 heat treated. 


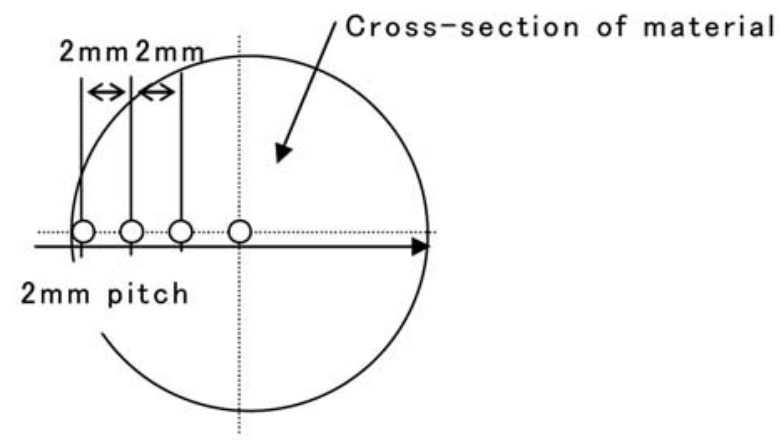

Fig. 13 Test method of hardness distribution of SUP9.

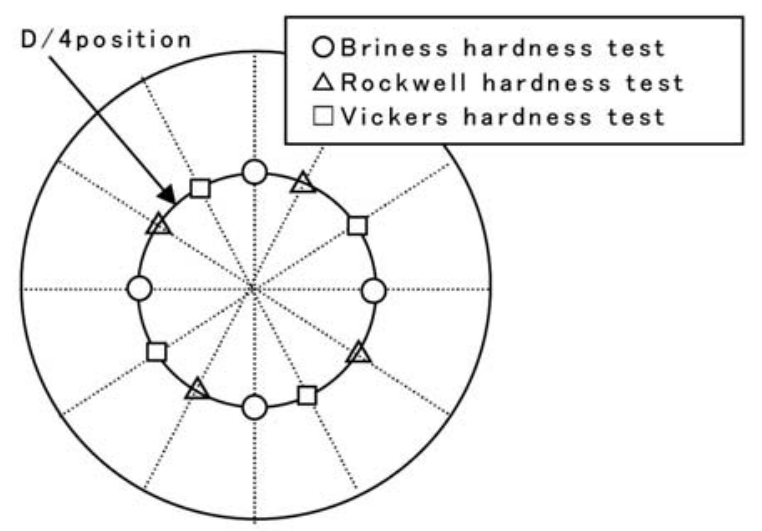

Fig. 15 Test method of hardness.

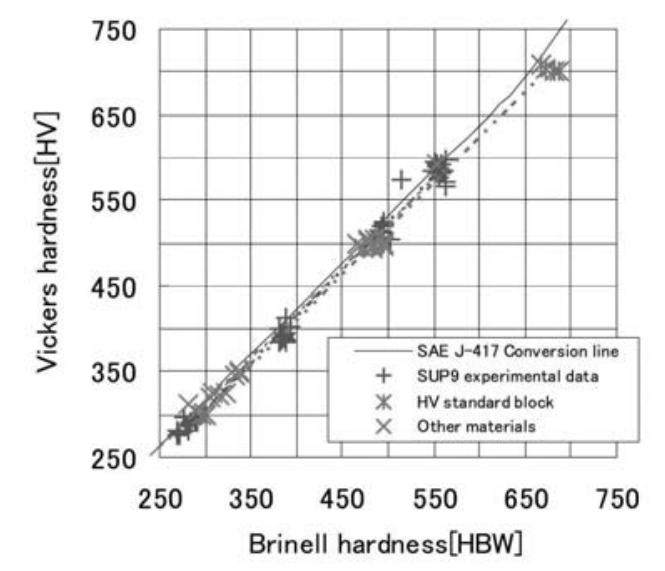

Fig. 17 Hardness conversion between Brinell and Vickers (distinction of steel grade).

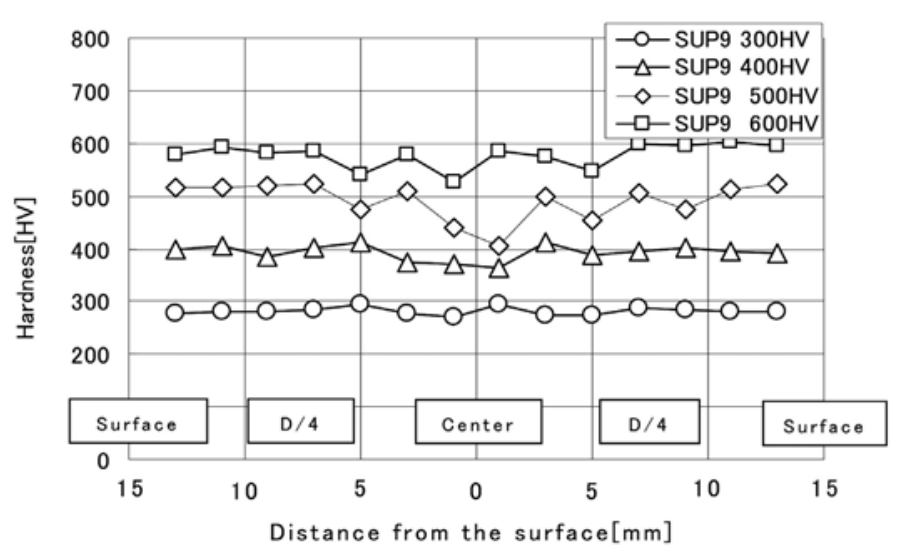

Fig. 14 Hardness distribution of SUP9.

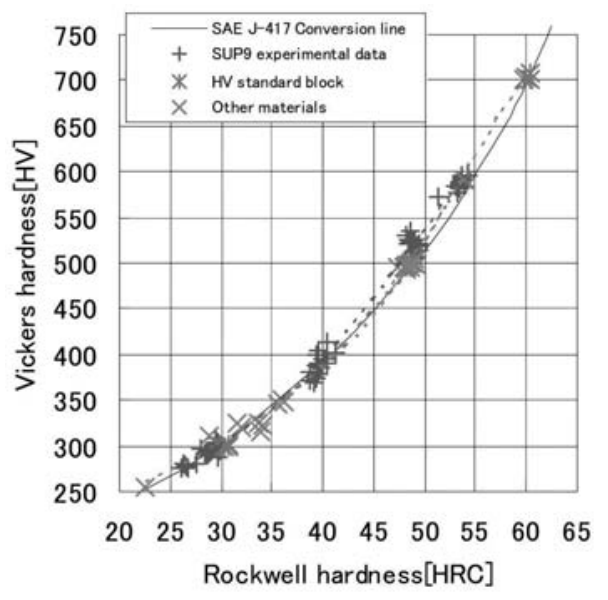

Fig. 16 Hardness conversion between Rockwell and Vickers (distinction of steel grade).

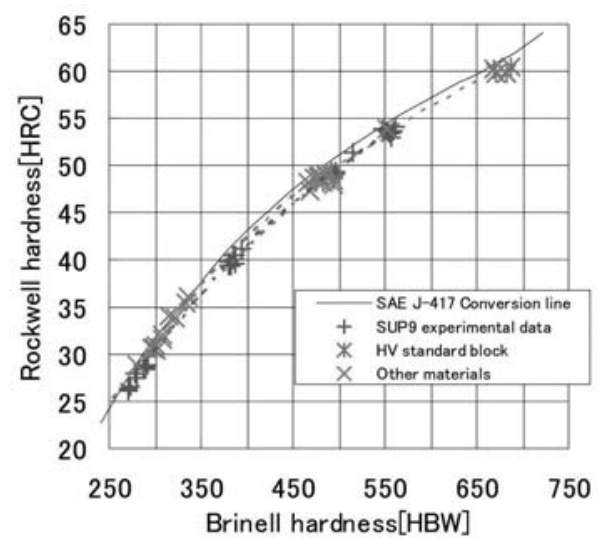

Fig. 18 Hardness conversion between Brinell and Rockwell (distinction of steel grade). 


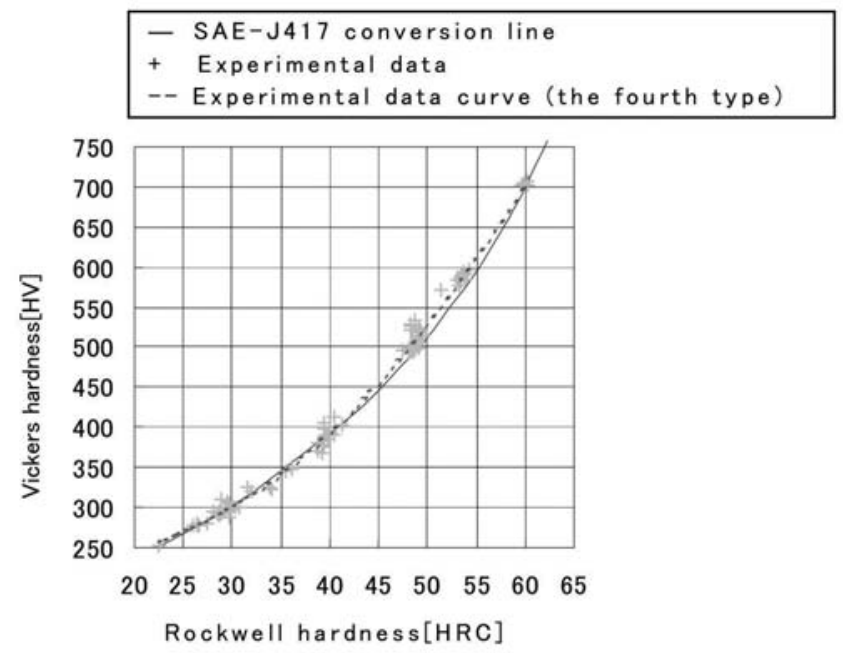

Fig. 19 Hardness conversion between Rockwell and Vickers (all data).

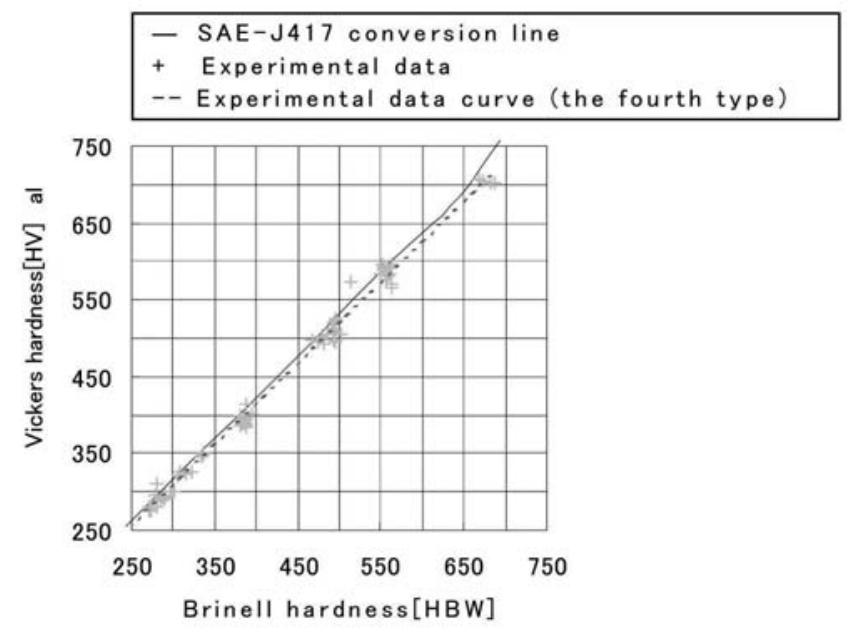

Fig. 20 Hardness conversion between Brinell and Vickers (all data).

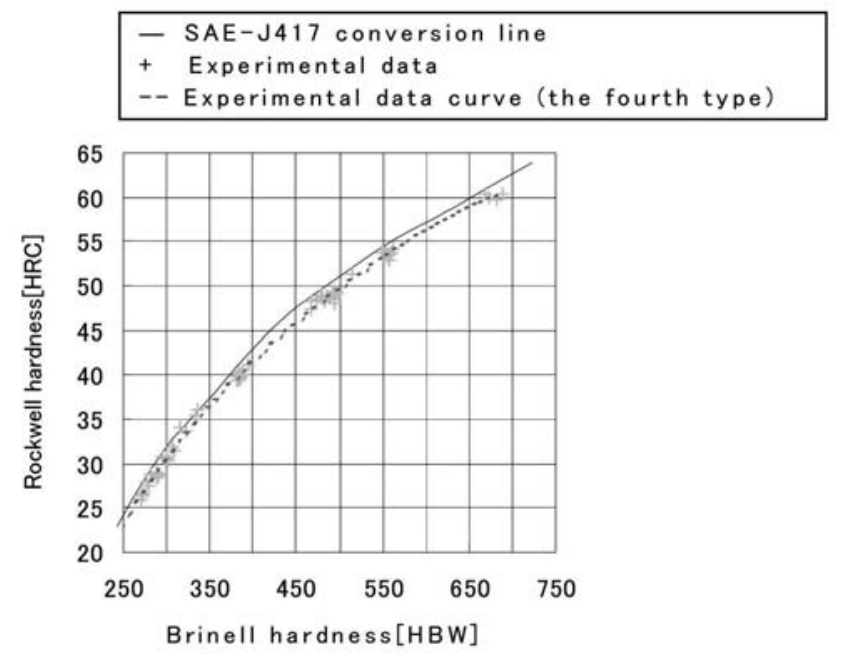

Fig. 21 Hrdness conversion between Brinell and Rockwell (all data).
Table 10 Chemical composition of test piece of SUP9.

(mass \%)

\begin{tabular}{|c|c|c|c|c|c|}
\hline $\mathrm{C}$ & $\mathrm{Si}$ & $\mathrm{Mn}$ & $\mathrm{Cr}$ & $\mathrm{P}$ & $\mathrm{S}$ \\
\hline 0.58 & 0.24 & 0.94 & 0.94 & 0.009 & 0.002 \\
\hline
\end{tabular}

Table 11 Hardness conversion table of Rockwell to Vickers and Brinell.

\begin{tabular}{|c|c|c|}
\hline HRC & HV & HBW \\
\hline 60 & 702 & 674 \\
\hline 59 & 684 & 653 \\
\hline 58 & 666 & 634 \\
\hline 57 & 648 & 615 \\
\hline 56 & 631 & 597 \\
\hline 55 & 613 & 580 \\
\hline 54 & 596 & 564 \\
\hline 53 & 579 & 548 \\
\hline 52 & 562 & 532 \\
\hline 51 & 546 & 518 \\
\hline 50 & 530 & 504 \\
\hline 49 & 514 & 490 \\
\hline 48 & 499 & 477 \\
\hline 47 & 484 & 464 \\
\hline 46 & 470 & 451 \\
\hline 45 & 456 & 439 \\
\hline 44 & 442 & 428 \\
\hline 43 & 429 & 416 \\
\hline 42 & 416 & 405 \\
\hline 41 & 404 & 394 \\
\hline 40 & 393 & 384 \\
\hline 39 & 381 & 374 \\
\hline 38 & 371 & 364 \\
\hline 37 & 360 & 354 \\
\hline 36 & 351 & 345 \\
\hline 35 & 341 & 336 \\
\hline 34 & 332 & 327 \\
\hline 33 & 324 & 318 \\
\hline 32 & 316 & 310 \\
\hline 31 & 308 & 302 \\
\hline 30 & 301 & 294 \\
\hline 29 & 294 & 287 \\
\hline 28 & 288 & 280 \\
\hline 27 & 282 & 273 \\
\hline 26 & 276 & 267 \\
\hline 25 & 270 & 261 \\
\hline
\end{tabular}


Table 12 Hardness conversion table of Brinell to Vickers and Rockwell.

\begin{tabular}{|c|c|c|}
\hline HBW & $\mathrm{HV}$ & HRC \\
\hline 700 & 733 & 61 \\
\hline 690 & 722 & 60 \\
\hline 680 & 711 & 60 \\
\hline 670 & 701 & 60 \\
\hline 660 & 690 & 59 \\
\hline 650 & 680 & 59 \\
\hline 640 & 669 & 58 \\
\hline 630 & 658 & 58 \\
\hline 620 & 648 & 57 \\
\hline 610 & 637 & 57 \\
\hline 600 & 626 & 56 \\
\hline 590 & 616 & 56 \\
\hline 580 & 605 & 55 \\
\hline 570 & 594 & 55 \\
\hline 560 & 584 & 54 \\
\hline 550 & 573 & 53 \\
\hline 540 & 562 & 53 \\
\hline 530 & 552 & 52 \\
\hline 520 & 541 & 51 \\
\hline 510 & 530 & 50 \\
\hline 500 & 520 & 50 \\
\hline 490 & 509 & 49 \\
\hline 480 & 499 & 48 \\
\hline 470 & 488 & 47 \\
\hline 460 & 477 & 47 \\
\hline 450 & 467 & 46 \\
\hline
\end{tabular}

\begin{tabular}{|c|c|c|}
\hline HBW & $\mathrm{HV}$ & HRC \\
\hline 450 & 467 & 46 \\
\hline 440 & 456 & 45 \\
\hline 430 & 445 & 44 \\
\hline 420 & 435 & 43 \\
\hline 410 & 424 & 42 \\
\hline 400 & 413 & 42 \\
\hline 390 & 403 & 41 \\
\hline 380 & 392 & 40 \\
\hline 370 & 381 & 39 \\
\hline 360 & 371 & 38 \\
\hline 350 & 360 & 37 \\
\hline 340 & 349 & 36 \\
\hline 330 & 339 & 34 \\
\hline 320 & 328 & 33 \\
\hline 310 & 318 & 32 \\
\hline 300 & 307 & 31 \\
\hline 290 & 296 & 29 \\
\hline 280 & 286 & 28 \\
\hline 270 & 275 & 27 \\
\hline 260 & 264 & 25 \\
\hline 250 & 254 & 23 \\
\hline 240 & 243 & 22 \\
\hline 230 & 232 & 20 \\
\hline 220 & 222 & 18 \\
\hline 210 & 211 & 16 \\
\hline 200 & 200 & 14 \\
\hline
\end{tabular}

Table 13 Hardness conversion table of Vickers to Rockwell and Brinell.

\begin{tabular}{|c|c|c|}
\hline $\mathrm{HV}$ & HRC & HBW \\
\hline 700 & 60 & 668 \\
\hline 690 & 59 & 658 \\
\hline 680 & 59 & 649 \\
\hline 670 & 58 & 640 \\
\hline 660 & 58 & 630 \\
\hline 650 & 57 & 621 \\
\hline 640 & 56 & 612 \\
\hline 630 & 56 & 602 \\
\hline 620 & 55 & 593 \\
\hline 610 & 55 & 584 \\
\hline 600 & 54 & 574 \\
\hline 590 & 54 & 565 \\
\hline 580 & 53 & 556 \\
\hline 570 & 52 & 546 \\
\hline 560 & 52 & 537 \\
\hline 550 & 51 & 528 \\
\hline 540 & 51 & 518 \\
\hline 530 & 50 & 509 \\
\hline 520 & 49 & 500 \\
\hline 510 & 49 & 490 \\
\hline 500 & 48 & 481 \\
\hline 490 & 47 & 472 \\
\hline 480 & 47 & 462 \\
\hline
\end{tabular}

\begin{tabular}{|c|c|c|}
\hline $\mathrm{HV}$ & HRC & HBW \\
\hline 470 & 46 & 453 \\
\hline 460 & 45 & 444 \\
\hline 450 & 45 & 434 \\
\hline 440 & 44 & 425 \\
\hline 430 & 43 & 416 \\
\hline 420 & 42 & 406 \\
\hline 410 & 42 & 397 \\
\hline 400 & 41 & 388 \\
\hline 390 & 40 & 378 \\
\hline 380 & 39 & 369 \\
\hline 370 & 38 & 360 \\
\hline 360 & 37 & 350 \\
\hline 350 & 36 & 341 \\
\hline 340 & 35 & 332 \\
\hline 330 & 34 & 323 \\
\hline 320 & 33 & 313 \\
\hline 310 & 31 & 304 \\
\hline 300 & 30 & 295 \\
\hline 290 & 28 & 285 \\
\hline 280 & 27 & 276 \\
\hline 270 & 25 & 267 \\
\hline 260 & 24 & 257 \\
\hline 250 & 22 & 248 \\
\hline
\end{tabular}

